\title{
Effect of Some Herbal Plants on Liver Function of Rats Treated with Trichloroethylene
}

\author{
L. M. ALGhwij, A. M. Ghoneim, A. E. Said and G. A. Abd-Allah \\ Biology Department Faculty of Science and Education., ALmergheb University., Libya \\ Zoology Department Faculty of Science., Damietta Branch Mansoura University., Egypt
}

\begin{abstract}
Background \& Aims: Curcumin (CCM), Cinnamon (CNN) and Ginger (GE) had been considered to possess antioxidant activities. This study aimed to investigate their protection effect against trichloroethylene (TCE)-induced hepatotoxicity and to demonstrate its possible mode of action.
\end{abstract}

Methods: Rats were fed CCM, CNN and GE singly with or without $5 \mathrm{mg} / \mathrm{l}$ of TCE in drinking water. The rat were killed after treatment period of 8 weeks, and the serum levels of alanine aminotransferase (ALAT), aspartate aminotransferase (ASAT), bilirubin, proteins, glucose, albumin and triglycerides were determined.

Results: TCE- receiving rat exhibited significant changes in biomarkers of liver function to indicate liver injury. The CCM containing diet significantly ameliorated the serum aminotransferases, especially ALAT, total protein and albumin. The CNN containing diet significantly ameliorated the total protein and albumin. The GE containing diet significantly ameliorated the serum aminotransferases, especially ALAT.

In conclusion, this work indicated that CCM is the most herbal plant which can protected and alleviated the liver function.

Key Words: Trichloroethylene - Curcumin - Cinnamon - Ginger - Rats

\section{Introduction}

Nowadays, there is an increasing interest in the protective function of dietary antioxidants, which play an important role in the protection of liver. CCM (diferuloyl methane) is a phenolic compound present in large quantities in the root of plant curcuma longa. It has been widely used as a spice and coloring agent in food. Recently, CCM has been considered to possess anti-inflammatory and antioxidant activities ( Anto et al., 2000). The ability of CCM to prevent tumor formation in the skin, forestomach, duodenum, and colon of mice and in the tongue, colon, mammary glands, and sebaceous glands of rats has been well documented (sharma et al., 2001).CCM has been also shown to inhibit lipid peroxidation caused by many toxic agents in hepatocytes either in vitro or in vivo (Ramirez Bosca et al.,1995; Devasena et al., 2002). On the other hand, no treatment-related toxicity was observed up to an oral dose of $8000 \mathrm{mg} /$ day for 3 month in mice (Chuang et al., 2000). This non toxic nature of CCM, as well as its multiple beneficial clinical effects, has made it one of the most attractive antioxidants.

CNN (Cinnamon), also known by Cassia, Sweet Wood, and Gui Zhi, is traditionally harvested in Asian 
countries(Leung, 1996; Toriizuka, 1998). Many studies have shown the diverse biological functions of cinnamon including anti-diabetic effects (Qin et al., 2003). anti-inflammatory (Lee et al., 2005), An antitumor effect of cinnamon was previously suggested in vitro (Schoene et al., 2005) without in vivo evidence or a working mechanism, and anti-microbial (Matan et al., 2006) and anti-oxidant (Singh et al., 2007).

In addition, Phenol compounds present in (cinnamon) spices that show natural anti-oxidant properties have been studied for substitution of synthetic anti-oxidants, due to possible side effects of synthetic anti-oxidants which may in some circumstances act deleterious to animal organisms (Pratt, 1992).

GE (Ginger), is one of the most widely used spices around the world and is a common condiment for a variety of compounded foods and beverages (Gupta, 2008). Ginger (Zingiber officinale Roscoe) has been used as a spice for over 2000 years (Bartley and Jacobs, 2000). Recently, ginger has received increasing attention because of its pronounced antioxidant (El- Ghorab et al., 2010), antiinflammatory (Minghetti et al., 2007), anti-diabetic (Afshari et al., 2007) anticancer activities (Shukla and Singh, 2007), anti-emetic, anxyolitic, antithrombotic, anti-pyretic, analgesic, and a treatment for toothache, insomnia, baldness, urinary tract infections, and as therapy for various gastrointestinal disorders (Balch, 1996), arthritis, rheumatism ( Dedov et al., 2002; Wang and Wang, 2005; Tapsell et al., 2006), sprains, muscular aches, pains, sore throats, cramps, constipation, indigestion, vomiting, hypertension, dementia, fever, infectious diseases and helminthiasis (Ali et al., 2008), and cardiovascular effects (Kaul and Joshi, 2001; Afzal et al., 2001).

The present study was thus designed to investigate the protective activity of CCM, CNN and GE against TCE-induced liver injury.

Selected routine work biochemical markers of liver function tests were chosen to express the effect.

\section{Material and methods}

Chemicals: Pure TCE was purchased from Sigma Chem. Co.(St. Louis, MO, USA).

Powedered CCM, CNN and GE was purchased from Libya spice market. Kits for biochemical measurements were supplied from Randox Labratories Ltd., UK.

Diets: Standard diet was prepared from Casein (20\%), Starch (32\%), Sucrose(33\%), Cellulose(5\%), Corn oil (5\%) and Vitamin / Mineral(5\%),( Abd-Allah ,2003).

\section{Animals and Treatments:}

Twenty five male albino Wistar rats ( weight range $58-160 \mathrm{~g}$ ) were used for the experimental study. Animals were obtained from hellwan animal station, Ministry of Heath, Egypt . The experimental rats were housed in the animal house in zoology Department, Faculty of Science, Damietta Branch, Mansoura University, New Damietta, Egypt . They were divided into 8 groups of 5 rats each.

Group 1: ( Normal) rats were given basal diet and water for 8 weeks.

Group 2: ( Trichloroethylene) rats were given 5\% TCE in drinking water for 8 Weeks.

Group 3: ( Curcumin) rats were given Curcumin at $1 \mathrm{~g} / \mathrm{kg}$ diet for 8 weeks.

Group 4:( Trichloroethylene + Curcumin) rats were given $5 \%$ Trichloroethylene in drinking water and Curcumin at $1 \mathrm{~g} / \mathrm{kg}$ diet for 8 weeks.

Group 5:( Cinnamon) rats were given Cinnamon at $1 \mathrm{~g} / \mathrm{kg}$ diet for 8 weeks.

Group 6:( Trichloroethylene + Cinnamon) rats were given $5 \%$ Trichloroethylene in drinking water and Cinnamon at $1 \mathrm{~g} / \mathrm{kg}$ diet for 8 weeks. 
Group 7 :( Ginger) rats were given Ginger at $1 \mathrm{~g} / \mathrm{kg}$ diet for 8 weeks.

Group 8 :( Trichloroethylene + Ginger) rats were given $5 \%$ Trichloroethylene in drinking water and Ginger at $1 \mathrm{~g} / \mathrm{kg}$ diet for 8 weeks.

\section{Sampling and Measurements:}

After 8 weeks of treatments, rats were killed by Anesthesia and the blood was withdrawn by syringe in to blood centrifuge tubes. Blood collected was allowed to coagulate at $37 \mathrm{c}^{\circ}$ for 30 minutes. Serum was separated by centrifugation at $4000 \mathrm{rpm}$ and used for the estimations of ALAT(Reitman and Frankel 1957), ASAT(Reitman and Frankel 1957), total Bilirubin (Walloy and Gerade 1970), albumin (Doumas et al., 1971), triglycerides (Vassault(1986), total protein (Gornal et al.,1949) and Glucose Trinder-reaction (1969).

Statistics: Student's $t$ test was used for statistical analysis of the data. The significant levels were considered as: $\mathrm{p} \leq$ $0.05, \mathrm{p} \leq 0.01$ and $\mathrm{p} \leq 0.001$, ( Millar 2001).

\section{Results}

\section{Serum Aminotransferases:}

Table (1) presents the results of serum ALAT and ASAT of rats treated with TCE with or without plant herbs.

Means of serum ALAT and serum ASAT were significantly higher in rats treated with TCE than that of normal animals. On the other, serum ALAT and ASAT did not changed in animals fed on herbs alone than that of normal ones.

On the effect of herbs the mean of serum ALAT was completely improved in rats treated with TCE /CCM, but no changes were observed with CNN and GE. No alleviation was resulted in serum ASAT of rats fed on all expremintel herbs.

\section{Liver function tests:}

Table (2) presents the results of serum concentrations of total protein, albumin and bilirubin of rats treated with TCE with or without plant herbs.

Means of serum total protein was significantly lower in rats treated with TCE than that of normal animals. On the other, serum total protein did not changed in animals fed on CCM and CNN alone than that of normal ones. On adding of Herbal plants to TCE treatment serum total protein was partially ameliorated with CCM and CNN .On the other hand, no significant changes were observed in rats treated with TCE/GE.

In similar, means of serum albumin was significantly lower in rats treated with TCE than that of normal animals. On the other, serum albumin did not changed in animals fed on CCM alone than that of normal ones. On adding of herbal plants to TCE treatment serum albumin was partially ameliorated with CCM and GE .

On the other hand, no significant changes were observed in rats treated with TCE/CNN.

Means of serum bilirubin was significantly higher in rats treated with TCE than that of normal animals. On the other, serum bilirubin did not changed in animals fed on herbs alone than that of normal ones. On adding of herbal plants to TCE treatment serum bilirubin was partially ameliorated with CCM and CNN . On the contrary, no improvement was observed on adding GE to TCE treatment.

\section{Serum Metabolites:}

Table (3) presents the results of serum concentrations of Triglycerides and Glucose of rats treated with TCE with or without plant herbs.

Means of serum triglycerides and serum glucose were significantly higher in rats treated with TCE than that of normal animals. On the other, serum triglycerides and glucose did not changed in animals fed on herbs alone than that of normal ones. 
Effect of Some Herbal Plants on Liver Function of Rats Treated with Trichloroethylene

On adding herbs to diet the mean of serum triglycerides was partially ameliorated in rats treated with TCE /CCM, but no changes were observed with
CNN and GE. No alleviation was resulted in serum Glucose of rats fed on all tested herbs.

Table (1): Activities of serum aminotransferases in rats treated with CCM, CNN and GE with TCE.

\begin{tabular}{|c|c|c|c|c|c|c|c|c|}
\hline Parameters & $\mathrm{C}$ & TCE & CCM & TCE+CCM & $\mathrm{CNN}$ & TCE+CNN & $\pm \mathbf{G E}$ & TCE+GE \\
\hline $\begin{array}{l}\begin{array}{l}\text { Alanine } \\
\text { aminotransferase(IU/I) }\end{array} \\
\text { Mean } \pm \mathrm{SD} \\
P \text {-value vs. control } \\
P \text {-value vs. TCE }\end{array}$ & $\begin{array}{l}16.0 \pm \\
2.12\end{array}$ & $\begin{array}{c}28.6 \pm \\
2.19 \\
* *\end{array}$ & $\begin{array}{c}15.4 \pm \\
1.34 \\
\text { NS }\end{array}$ & $\begin{array}{c}16.6 \pm 1.34 \\
* * *\end{array}$ & $\begin{array}{c}15.4 \pm \\
1.34 \\
\mathrm{NS}\end{array}$ & $\begin{array}{c}29.4 \pm 2.19 \\
* * *\end{array}$ & $\begin{array}{l}15.4 \pm \\
2.50 \\
\text { NS }\end{array}$ & $\begin{array}{c}23.8 \pm 1.78 \\
* * \\
* *\end{array}$ \\
\hline $\begin{array}{l}\begin{array}{l}\text { Aspartate } \\
\text { aminotransferase(IU/I) }\end{array} \\
\text { Mean } \pm \mathrm{SD} \\
P \text {-value vs. control } \\
P \text {-value vs. TCE }\end{array}$ & $\begin{array}{c}16.0 \pm \\
2.12\end{array}$ & $\begin{array}{c}32.2 \pm \\
3.83 \\
* *\end{array}$ & $\begin{array}{c}15.4 \pm \\
1.34 \\
\mathrm{NS}\end{array}$ & $\begin{array}{c}32.2 \pm 3.83 \\
* * *\end{array}$ & $\begin{array}{c}17.2 \pm \\
1.64 \\
\text { NS }\end{array}$ & $\begin{array}{c}34.0 \pm 2.74 \\
* * *\end{array}$ & $\begin{array}{c}19.4 \pm \\
3.51 \\
\text { NS }\end{array}$ & $\begin{array}{c}29.4 \pm 2.19 \\
* *\end{array}$ \\
\hline
\end{tabular}

Number of animals per group $=5 *$ significant, $* *$ and $* * *=$ significant higher, $* * * *=$ significant very higher, NS $=$ Non- significant value

Table (2): Serum Concentrations of serum metabolites in rats treated with CCM, CNN and GE with TCE.

\begin{tabular}{|c|c|c|c|c|c|c|c|c|}
\hline Parameters & $\mathrm{C}$ & TCE & CCM & TCE+CCM & CNN & TCE+CNN & GE & TCE+GE \\
\hline $\begin{array}{l}\text { Total protein } \\
\text { (g/dI) } \\
\text { Mean } \pm \text { SD } \\
\text { P-value vs. } \\
\text { control } \\
\text { P-value vs. } \\
\text { TCE }\end{array}$ & $\begin{array}{c}5.82 \pm \\
0.26\end{array}$ & $\begin{array}{c}5.46 \pm \\
0.15 \\
*\end{array}$ & $\begin{array}{c}7.01 \pm \\
0.65 \\
*\end{array}$ & $\begin{array}{c}6.23 \pm 0.18 \\
* \\
* *\end{array}$ & $\begin{array}{c}6.21 \pm \\
0.43 \\
\text { NS }\end{array}$ & $\begin{array}{c}6.68 \pm 0.66 \\
* \\
* *\end{array}$ & $\begin{array}{c}5.36 \pm \\
0.70 \\
*\end{array}$ & $\begin{array}{c}5.42 \pm 0.49 \\
\text { NS }\end{array}$ \\
\hline $\begin{array}{l}\begin{array}{l}\text { Albumin } \\
\text { (g/dI) }\end{array} \\
\text { Mean + SD } \\
\text { P-value vs. } \\
\text { control } \\
\text { P-value vs. } \\
\text { TCE }\end{array}$ & $\begin{array}{c}3.75 \pm \\
0.01\end{array}$ & $\begin{array}{l}3.13 \pm \\
0.02 \\
* * * *\end{array}$ & $\begin{array}{c}3.83 \pm \\
0.03 \\
* *\end{array}$ & $\begin{array}{c}3.59 \pm 0.03 \\
* * * \\
* * * *\end{array}$ & $\begin{array}{l}3.38 \pm \\
0.10 \\
* * *\end{array}$ & $\begin{array}{c}3.18 \pm 0.03 \\
* * * * \\
*\end{array}$ & $\begin{array}{l}3.17 \pm \\
0.02 \\
* * * *\end{array}$ & $\begin{array}{c}3.38 \pm 0.02 \\
* * * * \\
* * * *\end{array}$ \\
\hline $\begin{array}{l}\begin{array}{l}\text { Bilirubin } \\
(\mathbf{m g} / \mathbf{d I})\end{array} \\
\text { Mean } \pm \text { SD } \\
\text { P-value vs. } \\
\text { control } \\
\text { P-value vs. } \\
\text { TCE }\end{array}$ & $\begin{array}{c}0.22 \pm \\
0.06\end{array}$ & $\begin{array}{c}0.65 \pm \\
0.11 \\
* *\end{array}$ & $\begin{array}{c}0.26 \pm \\
0.02 \\
N S\end{array}$ & $\begin{array}{c}0.63 \pm 0.03 \\
* * * *\end{array}$ & $\begin{array}{c}0.31 \pm \\
0.05 \\
*\end{array}$ & $\begin{array}{l}0.58 \pm 0.04 \\
* * * *\end{array}$ & $\begin{array}{c}0.25 \pm \\
0.04 \\
\text { NS }\end{array}$ & $\begin{array}{c}0.74 \pm 0.14 \\
* *\end{array}$ \\
\hline
\end{tabular}

Number of animals per group $=5 *$ significant, $* *$ and $d^{* * *}=$ significant higher, $* * * *=$ significant very higher, NS = Non- significant value 
Table (3): Serum Concentrations of serum metabolites in rats treated with CCM, CNN and GE with TCE.

\begin{tabular}{|c|c|c|c|c|c|c|c|c|}
\hline Parameters & $\mathrm{C}$ & TCE & CCM & TCE+CCM & CNN & TCE+CNN & GE & TCE+GE \\
\hline $\begin{array}{l}\text { Triglycerides } \\
\text { (g/dI) } \\
\\
\text { Mean } \pm \mathrm{SD} \\
P \text {-value vs. } \\
\text { control } \\
P \text {-value vs. } \\
\text { TCE }\end{array}$ & $\begin{array}{c}70.5 \\
\pm 4.66\end{array}$ & $\begin{array}{c}180.4 \\
\pm 18.48 \\
* * *\end{array}$ & $\begin{array}{c}65.6 \\
\pm 7.05 \\
*\end{array}$ & $\begin{array}{c}159.1 \pm 11.96 \\
* * * \\
*\end{array}$ & $\begin{array}{c}73.6 \pm \\
8.96 \\
\text { NS }\end{array}$ & $\begin{array}{c}184.4 \pm \\
10.56 \\
* * * *\end{array}$ & $\begin{array}{c}70.9 \pm \\
9.37 \\
\text { NS }\end{array}$ & $\begin{array}{c}178.5 \pm \\
3.12 \\
* * * *\end{array}$ \\
\hline $\begin{array}{l}\begin{array}{l}\text { Glucose } \\
(\mathbf{m g} / \mathbf{d I})\end{array} \\
\text { Mean } \pm \text { SD } \\
\text { P-value vs. } \\
\text { control } \\
\text { P-value vs. } \\
\text { TCE }\end{array}$ & $\begin{array}{c}56.07 \pm \\
0.56\end{array}$ & $\begin{array}{c}102.79 \pm \\
2.77 \\
* * * *\end{array}$ & $\begin{array}{c}52.41 \pm \\
0.68 \\
* * *\end{array}$ & $\begin{array}{c}107.24 \pm 1.40 \\
* * * * \\
*\end{array}$ & $\begin{array}{c}55.66 \pm \\
1.09 \\
\text { NS }\end{array}$ & $\begin{array}{c}104.24 \pm \\
2.43 \\
* * * * \\
*\end{array}$ & $\begin{array}{c}55.24 \pm \\
0.69 \\
\text { NS }\end{array}$ & $\begin{array}{c}105.08 \pm \\
1.29 \\
* * * *\end{array}$ \\
\hline
\end{tabular}

Number of animals per group $=5 *$ * significant , $* *$ and $* * *=$ significant higher,$* * * *=$ significant very higher , NS = Non- significant value

\section{Discussion}

The toxicity of TCE is dependent on its metabolism, which occurs by either cytochrome p-450 ( p-450) -dependent oxidation or glutathione ( $\mathrm{GSH})$ conjugation. Metabolites derived from $\mathrm{p}$ 450 metebolism, including trichloroacetate ( TCA) and dichloracetate ( DCA), have been associated with the hepatotoxicity ( Davidson and Beliles, 1991; Lash et al., 1999).

The effect of TCE was agreed to that reported by (Maiti et al., 2004; Maiti et al., 2005 and Beppu et al., 2006). Many medicinal plants are used today in therapy of different diseases (Mascolo et al., 1989).

Curcumin Over the years, a number of studies have tried addressing the pharmacokinetics of that is poorly absorbed from intestine after oral administration of different doses of $3 \mathrm{H}$ scurcumin in rats (Ravindranath and Chandrasekhara, 1980, Ravindranath and Chandrasekhara, 1981 and Ravindranath and Chandrasekhara, 1982). It was shown that oral consumption of acurcumin in rats resulted in approximately $75 \%$ being excreted in the feces and only traces appeared in the urine (Wahlstrom and Blennow, 1978), converted to monoglucuronide conjugates (Pan et al., 1999).

In the present work, adding CCM to TCE treated rats was completely improved the results of ALAT and albumin, but the other parameters, total protein, bilirubin and Triglycerides, were partially alleviated. These results are more or less agreed to that obtained by Abd-Allah (2003). Because the measurement of serum ALAT and albumin are more from the intestine. Numerous studies have suggested presence of different metabolites of scurcumin. It has been shown to be bio-transformed to $11 \%$ found in bile (Holder et al., 1978) ,suggesting poor absorption of scurcumin of fecal excretion of scurcumin, with only dihydrocurcumin and tetrahydrocurcumin. the absolute abolishment of their increase closely indicate the ability of CCM to minize the TCE-induced liver injury in the present study. It may be argued that the ability of CCM to scavenge free radicals 
might have been responsible for its antioxidative activity. Moreover, it is also with the hepatic metabolism of TCE though the modulation of liver drug metabolizing enzymes involved in its biotransformation, i.e cytochrome $\mathrm{P} 450$ and glutathione-s- trasferase ( Sharma et al., 2001; Thapliyal and Maru, 2001).

Similarly, the interaction between TCE and CCM effects on the metabolism of proteins, carbohydrates and lipid may be attributed to the same issue or to the lipidlowering potent activity in vivo by the dietary curcuminoid ( Asia and Miyazawa, 2001) However, this point is still unclear and needs further investigations to be resolved and cleared up.

$\mathrm{CNN}$ is a popular flavoring ingredient, widely used in food products. It has exhibited beneficial properties to health, such as antimicrobial activity, for controlling glucose intolerance and diabetes, inhibiting the proliferation of various cancer cell lines, and for treating the common cold (Anderson \& Broadhurst, 2004; Murcia et al., 2004). CNN extracts can reduce lipid peroxidation in the (3-carotene-linoleic acid system (Mancini-Filho \& Van-Koiij, 1998). CNN extracts exhibit a protective capacity against irradiation induced lipid peroxidation in liposomes, and quench hydroxyl radicals and hydrogen peroxide (Murcia et al., 2004). Extracts on lard and vegetable oils demonstrated that they could stabilize lard against oxidation and showed antioxidative properties when tested on vegetable oils during storage or frying conditions (Vekiari, \& Thomopoulos, 1993).

In the present work, $\mathrm{CNN}$ was partially ameliorated the effect of TCE on the liver most selected biochemical markers, although total protein was showed completely improvement. Moselhy and Junbi (2010) observed that the elevated serum ASAT and ALAT enzymatic activities induced by $\mathrm{CCl} 4$ were restored possible that CCM might have interfered

towards normalization significantly by orally administrated $200 \mathrm{mg} / \mathrm{kg} \quad \mathrm{CNN}$ of either extracts once daily for 7 days as compared to non treated rats. The results obtained indicated that $\mathrm{CNN}$ extract have potent hepatoprotective action against $\mathrm{CCl} 4$ by lowering the MDA level and elevate the antioxidants enzymes activities. GE (Zingiber officinale Roscoe) is example of botanicals which is gaining popularity amongst modern physicians and its underground rhizomes are the medicinally useful part (Mascolo et al., 1989). Many studies were carried out on ginger and its pungent constituents, fresh and dried rhizome. Among the pharmacological effects demonstrated is antiplatelet, antioxidant, anti-tumour, antirhinoviral, antihepatotoxicity immunomodulatory, anti-tumorigenic, antiinflammatory, anti-apoptotic, antihyperglycemic, anti-lipidemic anti-emetic actions and anti arthritic effect (FisherRasmussen et al., 1991; Sharma et al., 1994 and Kamtchouing et al., 2002). Ginger is a strong anti-oxidant substance and may either mitigate or prevent generation of free radicals. It is considered a safe herbal medicine with only few and insignificant adverse/side effects (Ali et al., 2007).

In the present work, GE is partially ameliorated ALAT, ASAT, Triglycerides and albumin, but other biochemical markers did not showed changes.

There results are similar to the result of Sakr (2007), who observed that the Treating animals with ginger led to significant decrease in ALT and AST activity in albino rats. El-Sharaky et al., (2009) reported that the results showed significant lowering of serum ASAT, ALAT that Ginger extract was found to have a protective effect on $\mathrm{CCl} 4$ and acetaminophen-induced damage as confirmed by histopathological 
examination of the liver in rats (Yemitan and Izeqbu, 2006).

In conclusion, the present results showed that sleketed plant herbs induced either complete improvement or partial

\section{References}

Anto R J, Maliekal T T, and Karunagaran D (2000): 1- 929 Cells harboring ectopically expressed relA resist curcumininduced apoptosis. .J. Biol. Cheim., 275 (21): 1560115604.

Sharma R A, Ireson C R, Verschoyle R D, Hill $K$ A, Williams $M$ L, Leuratti C, Manson M M, Marnett L J, Steward W P, and Gescher A (2001): Effects of dietary curcumin on glutathione S-transferase and malondialdehyde-DNA adducts in rat liver and colon mucosa: relationship with drug levels. Gin.Cancer Res., 7: 1452-8.

Devasena T, Rajasekaran $\mathrm{K}$ N, and Menon P V (2002): Bis- 1,7- (2-hydroxylphenyl)hepta-1 ,6-diene -3,5-Dione (a curcurninanalog) ameliorates dmh-induced hepatic oxidative stress duringcolon carcinogenesis. Pharmacol.Res., 46 (1): 39-45. Chuang S E, Kuo M I, Hsu C H, Chen Cr, Lin L k, Lai G M, Hsieh C Y, and Cheng A L (2000): Curcumin-containing diet inhibits diethylnitrosamineinduced murine hepatocarcinogenesis Carcinogenesis., 21(2): 331-335.

Pratt D E (1992): Natural antioxidants from plant material. In: HO, C.I., Lee, C.Y., Huang, M.I. (Eds.), Phenolic Compounds in Food and their Effects on Health, Vol. 507. ACS Symposium Series American Chemical Society, Washington ., 54-71.

Gupta R K (2008): Ginger - a wonderful spice: An overview. Vegetos., 21: 1-10.

Minghetti P, Sosaz S, Cilurzo F, Casiraghi A, Alberti E, and Tubaro A (2007): Evaluation of the topical antiinflammatory activity of ginger dry extracts from solutions and plasters. Planta Medica., 73: $1525-1530$.

Shukla Y, and Singh M (2007): Cancer preventive properties of ginger: A brief review. Food and Chemical Toxicology., 45: 683-690.

Balch J F, and Balch PA (1996): Prescription for nutritional healing: A practical A-Z reference to drug-free remedies using vitamins, minerals, herbs \& food supplements. New York: Avery Publishing Group.

Dedov V N, Tran V H, Duke C C, Connor M, Christie M J, Mandadi S, and Roufogalis B D (2002): Gingerols: a novel amelioration on the effect of TCE on the liver. By comparison the CCM was the most potent whit normalize of most tested biochemical markers.

class of vanilloid receptor (VR1) agonists. British Journal of Pharmacology., 137 (6): 793-798.

Wang W H, Wang Z M (2005): Studies of commonly used traditional medicineginger. Journal of China Chinese Medicine., (30): 1569-1573.

Tapsell L C, Hemphill I, Cobiac L, Patch C S, Sullivan D R, Fenech M, Roodenrys S, Keogh J B, Clifton P M, Williams P G, Fazio V A, and Inge K E (2006): Health benefits of herbs and spices: the past, the present, the future. Medical Journal of Australia., 185 (4): 4-24.

Ali B H, Blunden G, Tanira $M O$, and Nemmar A (2008): Some phytochemical, pharmacological and toxicological properties of ginger (Zingiber officinale Roscoe): A review of recent research. Food and Chemical Toxicology., 46: 409-420.

Kaul P N, Joshi B S (2001): Alternative medicine: Herbal drugs and their critical appraisal. Birkhauser Verlag, Basel (Switzerland).

Afzal M, Al-Hadidi D, Menon M, Pesek J, and Dhami M S (2001): Ginger: an ethnomedical, chemical and pharmacological review. Drug Metab. Drug Interact., 18: 159_ 190.

Davidson I W F, and Beliles R P (1991): Consideration of the target organ toxicity of trichloroethylene-in terms of metabolite toxicity and pharmacokinetics. Drug Metab. Rev., 23: 493-499.

Lash L H, Lipscomb J C, Putt D A, and Parker J C (1999): Glutathione conjugation of trichloroethylene in human liver and kidney: kinetics and individual variation. Drug Metab. Dispos., 27(3): 35 1-359.

McAuff M A, Omoruy F O, Morrison E Y, and Asemota $\mathrm{H}$ N (2003): Lipid management among coronary artery disease patients in diabetes mellitus or advanced age. Am. J. Cardiol., 87: 646-664.

Maiti R, Jana D, Das U K, and Ghosh D (2004): Antidiabetic effect of aqueous extract of seed of Tarmarindus indica in streptozotocin-induced diabetic rats. $J$. Ethnopharmacol., 92: 85-91. 
Maiti R, Das U K, and Ghosh D (2005): Attenuation of hyperglycemia and hyperlipidemia in streptozotocin induced diabetic rats by aqueous extract of seed of Tarmarindus indica. Biol. Pharm. Bull., 28: 1172-1176.

Beppu H, Shimpo K, Chihara T, Kaneko T, Tamai I, Yamaji S, Ozaki S, Kuzuya H, and Sonoda $S$ (2006): Antidiabetic effects of dietary administration of Aloe arborescens Miller components in multiple low-dose streptozotocin-induced diabetes in mice: Investigation on hypoglycemic action and systemic absorption dynamics of aloe components. J. Ethnopharmacol., 103: 468477.

Mascolo N, Jain R, Jain S C, and Capasso F (1989): Ethnopharmacologic investigation of ginger (Zingiber officinale). $J$. Ethnopharmacol., 27: 129-140.

Afshari A T, Shirpoor A, Farshid A, Saadatian R, Rasmi Y, and Saboory E (2007): The effect of ginger on diabetic nephropathy, plasma antioxidant capacity and lipid peroxidation in rats. Food Chemistry., 101: 148-153.

Dufour D R, Lott J A Nolte F S, Gretch D R, Koff $R$ S, and Seefe L B (2000): Diagnosis and monitoring of hepatic injury. 1. Performance characteristics of laboratory tests. Clin. Chem., 46(12): 2027-2049.

Thapliyal, R. and Maru, G. B. (2001): Inhibition of cytochrome P450 isozymes by curcumins in vitro and in vivo. Food Chem. Toxicol., 39(6): 541-547.

Asai, A. and Miyazawa, T. (2001): Dietary curcuminoids prevent high-fat diet-induced lipid accumulation in rat liver and epididymal adipose tissue. J. Nutr.,131 (11) :2932-2935.

Anderson $R$ A, Broadhurst C L, Polansky $M$ M, Schmidt W F , Khan A, and Flanagan $V \quad P$ (2004): Isolation and characterization of polyphenol type-A polymers from cinnamon with insulin-like biological activity. J Agric Food Chem., 52:6570.

El-Ghorab A H, Nauman M, Anjum F M, Hussain S, and Nadeem M (2010): A comparative study on chemical composition and antioxidant activity of ginger (Zingiber officinale) and cumin (Cuminum cyminum). Journal of Agricultural and Food Chemistry., 58: 8231-8237.

Ramirez Bosca A, Soler A, Gutierrez M A C, Alvarez J L, and Almagro E Q (1995): Antioxidant Curcuma extracts decrease the blood lipid levels of human subjects. Age., 18:167-9.

Fisher-Rasmussen W, Kjaer S K, Dahl C, and Asping $U$ (1991): Ginger treatment of
Hyperemesis gravidarm. Eur. J. Obstet. Gynecol. Rep. Biol., 38 (1): 19-24.

Sharma J N, Srivastava K C, and Gan E K (1994): Suppressive effects of eugenol and ginger oil on arthritic rats. Pharmacol., 49 (5): 314-318.

Kamtchouing P, Mbongue Fandio G Y, Dimo T, and Jatsa H B (2002): Evaluation of androgenic activity of Zingiber officinale and Pentadiplandra brazzeana in male rats. Asian J. Androl., 4 (4): 299-301.

Murcia M A, Egea I, Romojaro F, Parras $P$, Jiménez A M, and Martinez-Tome M (2004): Antioxidant evaluation in dessert spices compared with common food additives. Influence of irradiation procedure. Journal of Agricultural and Food Chemistry., 52:18721881.

Mancini-Filho J, and Van-Koiij A (1998): Antioxidant activity of cinnamon (Cinnamomum Zeylanicum, Breyne) extracts. Bollettino Chimico Farmacéutico., 137:443447.

Vekiari S A, Oreopoulou V, Tzia C, and Thomopoulos C D (1993): Oregano flavonoids as lipid antioxidants. Journal of the American Oil Chemists Society., 70:483-487.

Ravindranath, $\mathbf{V}$ and Chandrasekhara $\mathbf{N}$ (1980): Absorption and tissue distribution of curcumin in rats, Toxicology., $16: 259-265$.

Ravindranath $\mathbf{V}$, and Chandrasekhara $\mathbf{N}$ (1981): In vitro studies on the intestinal absorption of curcumin in rats, Toxicology., 20 : 251-257.

Ravindranath V, and Chandrasekhara $\mathbf{N}$ (1982): Metabolism of curcumin-studies with [3H] curcumin, Toxicology., 22: 337-344.

Wahlstrom B O, and Blennow G (1978): A study on the fate of curcumin in the rat, Acta Pharmacologica et Toxicologica., 43: 86-92.

Holder G M, Plummer J L, and Ryan A J (1978): The metabolism and excretion of curcumin (1,7-bis-(4-hydroxy3methoxyphenyl)-1,6-hepadiene-3,5-dione) in the rat, Xenobiotica ., 8: 761-776.

Pan M H, Huang $T$ M, and Lin $J \mathbf{K}$, (1999): Biotransformation of curcumin through reduction and glucuronidation in mice, Drug Metabolism and Disposition., 27:486494.

Yemitan $O \mathrm{~K}$ and Izeqbu $M$ C (2006): Protective effects of Zingiber offcinale (Zingiberaceae) against carbon tetrachloride and acetaminophen-induced hepatotoxicity in rats. Phytother. Res., 20(11):997-1002.

Leung F S, A Y (1996): in: Encyclopedia of common natural ingredients used in foods, drugs, and cosmetics, second ed., Wiley, New York., 168-170. 
Toriizuka K (1998): Basic lecture of Kampo medicine: pharmacological effect of cinnamon. Kampo Med., 11: 431-436.

Lee S H, Lee S Y, Son D J, Lee H, Yoo H S, Song S, Oh K W, Han D C, Kwon B M, and Hong J T (2005): Inhibitory effect of 20-hydroxycinnamaldehyde on nitric oxide production through inhibition of NF-[kappa]B activation in RAW 264.7 cells, Biochem. Pharmacol., 69: 791- 799.

Singh G, Maurya S, deLampasona M P, and Catalan C A N (2007): A comparison of chemical, antioxidant and antimicrobial studies of cinnamon leaf and bark volatile oils, oleoresins and their constituents, Food Chem. Toxico., 45: 1650-1661.

Matan N, Rimkeeree H, Mawson A J, Chompreeda P, Haruthaithanasan V, Parker M (2006): Antimicrobial activity of cinnamon and clove oils under modified atmosphere conditions, Int. J. Food Microbiol., 107: 180-185.

Qin B, Nagasaki M, Ren M, Bajotto G, Oshida Y and Sato Y (2003): Cinnamon extract (traditional herb) potentiates in vivo insulin-regulated glucose utilization via enhancing insulin signaling in rats, Diab. Res. Clin. Pract., 62 : 139-148.

Schoene N W, Kelly M A, Polansky M M, and Anderson R A (2005): Watersoluble polymeric polyphenols from cinnamon inhibit proliferation and alter cell cycle distribution patterns of hematologic tumor cell lines, Cancer Lett., 230: 134-140.

Sakr A ( 2007): Ameliorative Effect of Ginger (Zingiber officinale) on Mancozeb Fungicide Induced Liver Injury in Albino Rats, Australian Journal of Basic and Applied Sciences., 4: 650-656.

El-Sharaky A S, Newairy A A, Kamel M A, and Eweda S M ( 2009): Protective effect of ginger extract against bromobenzeneinduced hepatotoxicity in male rats, Food and Chemical Toxicology.,47: 1584-1590.

Abd-Allah, G A (2003):Curcumin counteracts trichloroethylene induced liver injury in mice. J. Egypt. Ger. Soc. Zool., 40 (A): 19-32.

Moselhy S, Junbi H (2010): Antioxidant properties of ethanolic and aqueous Cinnamon extracts against liver injury in rats.International Journal of Advances in Pharmaceutical Sciences., (1): 151-155.

Ali T A, Alireza S, Amirabbas F, Yousef R.; Ehsan S, Behrooz L, and Abdolamir A (2007): The effect of ginger on diabetic nephropathy, plasma

antioxidant capacity and lipid peroxidation in rats, Food Chemistry., 101: 148-153.

Walters M I, Gerarde H (1970):Microchem J., 15:(231).

Vassault A (1986): Ann.Biol.Clin., 44:(686).

Reitman S,and Frankel S (1957): A colorimetric method for the determination of serum glutamate oxaloacetic and glutamate pyruvic transaminases .Am.J.Clin. pathol., 28 (1): 56-63.

Trinder, P.(1969): Determination of glucose in blood using glucose oxidase with an alternative oxygen acceptor.Ann Clin. Biochem., 6:24-27.

Gornal A C, Bardawill C J, and David M M (1949): Determination of serum proteins by means of the biuret method.J.Bio.Chem.,177:571.

Doumas B T, Watson W A, and Bigge H G (1971):Automated determination of serum albumin with Bromocersol Green. Clin.Chem.Acta., 31: 78-96.

Millar N (2001): Biology statistics made simple using Excel. School Sci. Rev.,83(303): 23-34. 


\title{
تأثير بعض النباتات العشبية على وظائف الكبد فى الفأران

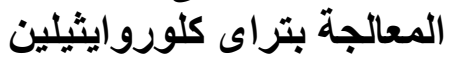

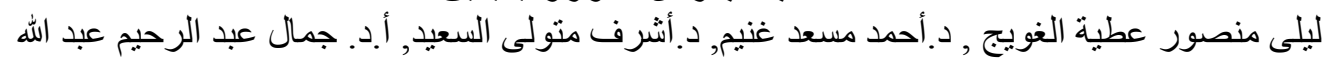

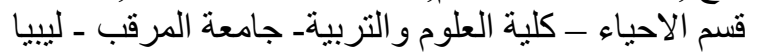 \\ قسم علم الحيو ان - كلية العلوم بدمياط - جامعة المنصورة ـ دمياط الجديدة - مصر
}

الكركم والقرفة والزنجبيل هى مركبات فينولية من أصل نباتى تستخدم بكثرة كتو ابل للطعام ـ وقد وجد حديثا أن

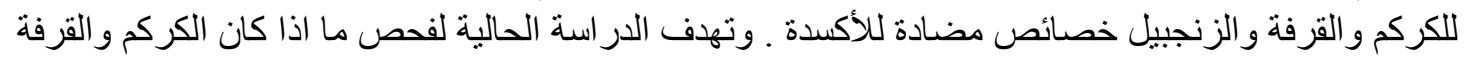

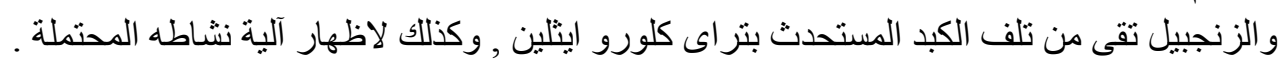

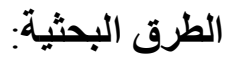

تم استخدام أبعون من ذكور الجرذان البيضاء تنراوح أوزانهم بين 85 - 160 جم في الدراسة التجريبية ـ نم

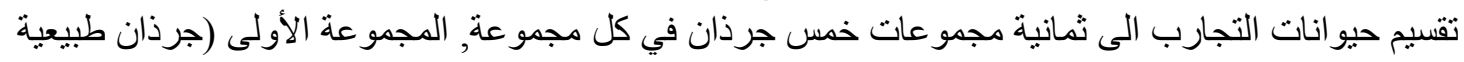

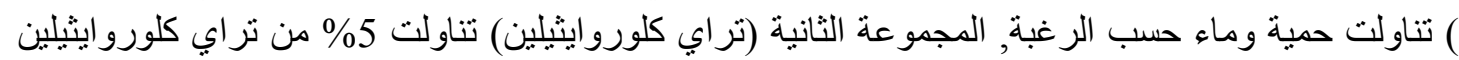

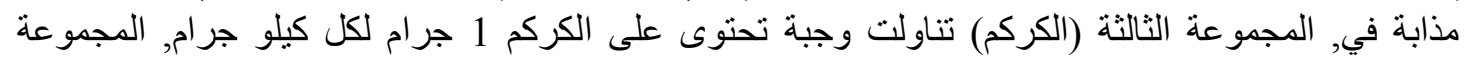

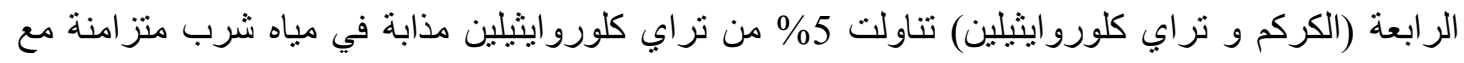

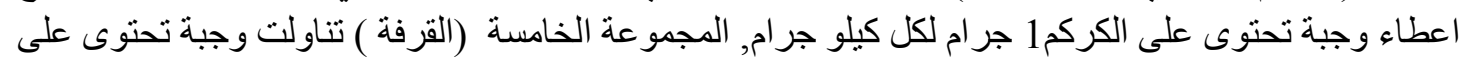

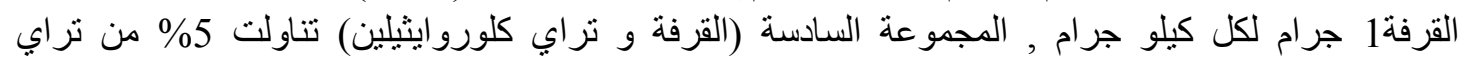

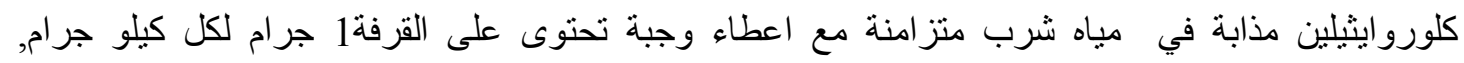

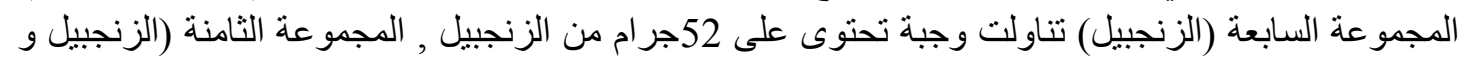

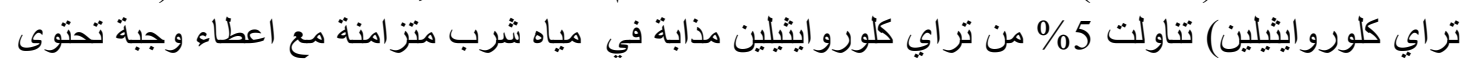

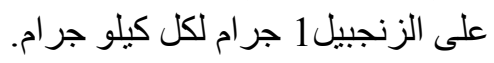

النتائج:

أظهرت مجموعة الفئران المعاملة بتراي كلورو ايثلين نمودج لوطأة الاكسدة فى الكبد (الاكسدة الفوقية فى

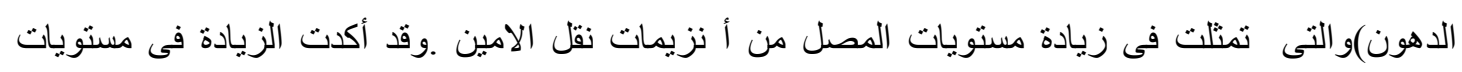

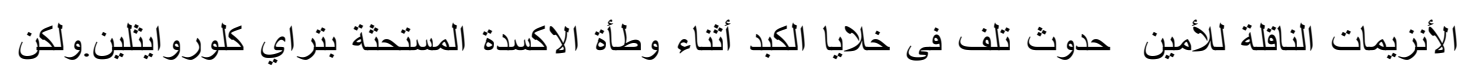

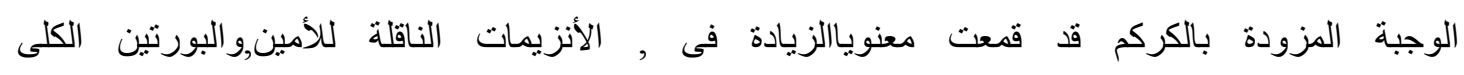

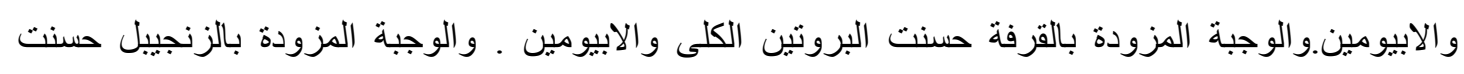
وبشكل كبير أنزيمات نقل الأمين.

الخلاصة:

أظهرت الدراسة الحالية الى ان الاعشاب المختبرة أدت اما الى تحسن كامل أو جزيئ على تأثير بتراى كلورو ايثلين على الكبد. و على سبيل المقارنة كان الكركم أكثر قوة فى التحسين الى الطبيعى , من قبيل الاعثاب المختبرة. 